\title{
Deep Ecology Philosophy and Biodiversity Conservation in Nigeria's Niger Delta
}

\author{
By Mark Omorovie Ikeke ${ }^{1}$
}

\begin{abstract}
Biodiversity refers to the varieties, multiplicity, and diversity of life in the ecosystem. It is being lost on a daily basis in Nigeria's Niger Delta. This is as a result of the environmental degradation caused by oil exploration and gas activities. In the process of drilling for oil and exploring for gas resources, the natural environment such as plants, animals and their communities is destroyed and endangered. Oil exploration activities continue unabated in the Niger Delta. There is need to combat biodiversity loss if not many of the benefits from biodiversity will be lost. With critical analysis the philosophy of deep ecology is examined and presented as having potentials to contribute to conserving biodiversity in Nigeria's Niger Delta. The paper concludes that there is vital need to preserve biodiversity using deep ecology values.
\end{abstract}

Keywords: Deep ecology, biodiversity, conservation, Niger Delta, Nigeria, and Philosophy

\section{Introduction}

Biodiversity is a fundamental value that is now recognized as necessary and essential for the survival and wellbeing of every human society. The preservation of various and all types of non-human species has benefits for humanity and this is well acknowledged by the United Nations (1992), Ikomi \& Arimoro (2010), Brown (2010), Francis (2015), and Ukaga, Ukoha \& Ibaba (2012). In many areas in the world such as the Amazon, the Congo, the Niger Delta, and Madagascar biodiversity is seriously threatened. There is serious need to stop biodiversity loss. The United Nations (1972) is forthright in asserting that natural resources of the earth which includes wildlife, flora and fauna and ecosystems are to be conserved and protected from all forms of pollution.

The fundamental thrust of this essay is to show that biodiversity in Nigeria's Niger Delta is endangered by oil exploration activities. This endangerment need to be stopped to preserve the wellbeing of the Niger Delta. In furtherance of this thesis, the basic terms are examined. This is followed by showing the loss of biodiversity in the Niger Delta. Then the philosophy of Deep Ecology is unveiled and applied to conserving biodiversity in the region. With that done the paper offers concluding reflections.

\section{Understanding the Basic Concepts}

Biodiversity has to do with life and all its varieties and species on earth. Biodiversity which is a short form of biological diversity means according to Micheals (2004): 'a wide variety of plant and animal life' (p. 52). Stranks (2008) says it means 'the 
range of plant and animal species and communities associated with terrestrial, aquatic and marine habitats' (p. 39). Hook (2008) writes that: 'There are many different definitions of "biodiversity", but broadly the term describes the range of different life forms that can be found in a given location or region' (p.29). You can say as Rajagopalan (2011) avers that it refers to: 'the numbers, variety, and variability of living organisms and ecosystems' and 'the term includes all the terrestrial, marine and other aquatic organisms' (p. 67). Asthana \& Asthana (2010) note that it is microbes, plants and animals in their ecosystems. It would be inappropriate not to state what the United Nations (1992) states on biodiversity as the variability of living organisms and their ecosystems.

Many definitions have been given above for a clear understanding of the term and in order to decipher how it will be used here. It is a truism that when you speak of the biological study of life it is inclusive of human life and the cosmos, not only that of nonhuman species, but as the term biodiversity has been understood the focus is on nonhuman life and species. It is therefore contrasted with bio-cultural diversity which focuses not just on non-human life but also human life and its cultural relationship with other species. It is humans who speak about biodiversity. The focus when using the term biodiversity is on non-human life forms. Biodiversity is inclusive of all plant life, and non-human animal life in relationship with the communities in which they live.

This paper argues that deep ecology has positive implications for biodiversity conservation in the Niger Delta. What then is conservation? Chambers (1994) defines the word, conserve as: 'the act of conserving especially old buildings, flora, and fauna, the environment' (p. 364). This dictionary also says it means to keep whole, safe, and unharmed and undamaged state. In Micheals (2004) it is to use resources in such a way as to keep them from wastage and only when necessary. As noted by Srivastava (2010) biodiversity conservation is 'human efforts to collect, reverse, prevent or discontinue activities that are causing decline in biodiversity like pollution, deforestation, etc' (p. 123). Biodiversity preservation is not just to preserve or keep alive the species of plants and animals and their ecosystems for present but also for future generations. It is aimed at the flourishing of all biodiversity.

The Niger Delta that is spoken of here is in southern Nigeria. It is often equated with the south-south of Nigeria. Ugochukwu as cited by Demaki (2015) indicates that the Niger Delta area is:

..the world third largest wetland covering a vast coastal plain estimated at 70,000 square kilometers in the central region of Southern Nigeria. It is the third largest mangrove forest with the most expansive fresh water swamp forest characterized by high concentration of biological diversity and endemism and endowed with vast renewable natural resources particularly deposits with oil and gas. It is a region of critical economic and ecological significance. p. 78-79

The Federal Government of Nigeria (2006) describes the Niger Delta as: 'The region situated in the southern part of Nigeria and bordered to the south by the Atlantic Ocean and to the East by Cameroon, occupies a surface area of about 112,110 square kilometers...' and is made up of Bayelsa, Delta, Edo, Rivers, Cross Rivers, Akwa Ibom, Imo, Ondo, and Abia (p. 49-50). The region is the economic mainstay of the Nigerian state as the oil and gas revenue from the region brings into the coffers of the federation 
the highest income. In more than five decades of oil exploration a great deal of environmental degradation that has destroyed biodiversity has taken place in the region. If this continues unabated human life, human culture, and biodiversity will continue to be damaged.

In order to combat the ravages of environmental degradation caused mainly by oil pollution and related oil activities, aspects of the wisdom of the philosophy of deep ecology can be helpful. It is never implied in this essay that only deep ecology has a contribution to make, but for this essay the concern is with deep ecology. Deep ecology is the green philosophy proposed by the Norwegian philosopher Arne Naess who according to Smith (1997) proposed a 'vision of biocentric, radically egalitarian' ethics. In deep ecology humans are perceived as being in integrated relationships with other beings and all beings should be seen as ends not means (Smith 1997). In Keller (2009) those who advocate for a deep ecology critiqued a human-centered value system that refuses to acknowledge the intrinsic value in nature. The above will suffice in defining deep ecology for now as it will be examined later. It is to the situation of the death and destruction of biodiversity in the Niger Delta that the paper now turns.

\section{The Loss of Biodiversity}

The United Nations Development Programme (2012) in her Niger Delta Biodiversity Project has described in details the rich biodiversity in the region which she considers to be the four oil producing states of Baylesa, Delta, Rivers and Akwa Ibom. It is important to read that document to get a detail listing of the biodiversity species which includes various species of fish, amphibians, reptiles, forest, etc. Rich biodiversity equally exists in the other states of the official Niger Delta.

From the beginning of human civilization there is no human society whose activities have not in one way or the other endangered or negatively impacted biodiversity. This negative impact has heightened in the modern industrial and technological age coupled with the growth of globalization. This is an age that is heavily dependent on oil and gas resources to run its industries and factories. Wherever oil and gas are discovered they are subject to being explored with technological machines in order to mine for those oil and gas. Nigeria's Niger Delta has not been an exception. In the process of oil and gas exploration in the Niger Delta a great proportion of plants, animals, and other organisms have been destroyed. The United Nations Development Programme (2012) has related that: "The primary threats to biodiversity in the Niger Delta are: Pollution; Habitat degradation and land-use change; Over-harvesting of natural resources, and; Invasive alien species' (p. 31).

To argue that, there is no biodiversity loss in the Niger Delta will not be true. Many sources have testified to the destruction of biodiversity in the Niger Delta. Biodiversity exists among the mountains, rivers, landscapes, and entire surroundings. One of the main economic activities that take place in the Niger Delta that causes biodiversity loss is the drilling and exploration for oil and gas resources. In the process of searching for oil and gas; oil multinational companies bring heavy oil equipment. Bulldozers and caterpillars are used to clear both virgin and renewable forests. Roads are made through farmlands and forests. Pipelines are dug to cart the oil away to the coast for export. 
There is constant phenomenon of digging the soil to lay pipelines in the Niger Delta. In the experience of this present author when the trees and forests are felled to lay pipelines the trees are just thrown disorderly into the neighboring land. There is no way that you can drill for oil without destroying plants and animals. The negative impact of the extractive industries and other anthropogenic factors on biodiversity in the region is acknowledged by many scholars Zabby (2004), Ugochukwu \& Ertel (2008), Kadafa (2012), Mmon \& Arukoyo (2009), and Agbagwa (2014).

In terms of animals, a wide varieties use to be common in the Niger Delta. The urbanization of many towns into cities, the building of oil companies and oil drilling facilities, and roads has destroyed the habitat of many animals. Ekpo (2004) narrates that after the discovery of oil till date people in Oguagba, Edo State have complained that their ecosystems have been destroyed and the flora and fauna are at a stage of extinction; and this is compounded by the constant pollution of land and the atmosphere. As Ekuerhare (2007) relates through death and degradation, fishes and other organisms in the rivers and environment of the region are no more and this has been caused by gas flaring and other oil activities. Moro (2008) equally bemoans the impact of oil activities and gas flares by stating that the abundant fishes in the rivers have disappeared and those that are left are poisoned as a result of chemical pollution by oil companies and seismic activities. Various ethnic groups of the Niger Delta in various bills of rights such as the Ogoni Bill of Rights by the Movement for the Survival of the Ogoni People (1990), and the Kalama Declaration of the Ijaw Youths of the Niger Delta (1998) have all expressed that their plants and animals and environment have been destroyed by oil companies. Further resources showing that there is constant destruction of biodiversity in the Niger Delta are too many to be enumerated here but they include Adeola (2009), Nwaomah (2011), and Glazebrook \& Olusanya (2011).

The fact is clear that there is biodiversity loss in the region. When there is biodiversity loss a great deal of the benefits that they bring is lost. These include as Srivastava (2010) and Rajagopalan (2011) note: loss of food, fuel, drugs, fiber, pharmaceutical resources, social-cultural values, aesthetic value, ecosystem services, etc. In the Niger Delta valuable sources of food, medicine, culture and even tourism has been lost as a result of devastation caused by oil companies. In the midst of biodiversity loss the philosophy of deep ecology can offer a contribution.

\section{The Philosophy of Deep Ecology}

Let it be said right away only some key aspects of deep ecology will be presented here as it is not possible to dwell on it fully here. It is a truism that this philosophy comes essentially from Arne Dekke Eide Naess, a Nowergian philosophy professor who in his 1973 essay, 'The Shallow and the Deep, Long-Range Ecology Movement' discussed environmental principles of activism; as Curry (2006) remarks. This principal founder of deep ecology was born in 1912 at Norway and became professor of philosophy at University of Oslo from the late thirties to the year nineteen seventy. He died in the year 2009. He was deeply involved both in environmental philosophy and movement in his country. Others who have also supported this movement in their writings are Bill Devall, George Sessions, and Warwick Fox. 
An important aspect of Deep Ecology is what is called the platform. The eight points in the platform as enumerated by Naess ((2013) are: (1) all beings have intrinsic value, (2) diversity and variety are values, (3) humans can make use of nature only for essential needs, (4) there is need to decrease human population to conserve other beings, (5) vital life processes are being destroyed by humans, (6) socio-economic policies should be made to reverse environmental degradation, (7) standard of life is not more important than quality of life, and (8) there is a moral obligation for those who accept the above principles to act for ecological conservation. Naess (2013) remarks that: '....in the deep ecology movement we are biocentric or ecocentric. For us it is the ecosphere, the whole planet, Gaia, that is the basic unit, and every living being has an intrinsic value' (p. 34). Taking statements directly from Naess, Cooper (2001) writes that:

Deep ecology is deep because it explores the 'fundamental presuppositions' of our values and experience of the world. It is deep ecology, not because it is the empirical science of ecosystems, but because the attitudes it endorses, though inspired by several sources, receive 'rational justification' from the ecologists' demonstration of 'the intimate dependency of humanity upon decent behaviour towards the natural environment'. p. 213

Naess (1973) says shallow ecology is human-centered and is simply concerned with pollution, resource depletion and the health and wellbeing of people in advanced countries. At the heart of deep ecology is the call for biocentric egalitarianism, selfrealization, and intrinsic value of biodiversity among many other values. Deep Ecology affirms that all beings have intrinsic value and non-human beings do not simply exist for human usage. Naess affirms that the self includes all and all beings have equal value. Cooper (2001) has noted that Naess took his notion of self from Spinoza's concept of one substance (God or nature) and the Hindu concept of Atman (self). Humans are one with nature and should experience nature as such, Naess opines. In the words of Taylor \& Zimmerman (2008); 'In the last analysis, for Naess, it is personal experiences of a profound connection with nature and related perceptions of nature's inherent worth or sacredness, which gives rise to deep ecological commitments' (p. 458). He notes that humans realize themselves by identifying with nature and working for the good of the whole of nature. Humans according to Naess (2013) have to make sacrifice to improve their quality of life even if it implies decreasing human populations, ending affluent and consumerist lifestyles.

\section{Deep Ecology and Biodiversity Conservation}

Deep ecology is not necessarily a cure-all to the problem of biodiversity loss in the Niger Delta. Deep ecology has its own limitations or unanswered questions. Smith (1997) notes that deep ecology falls into the dilemma of seeing all interests as par in all situations. What about the interests of an owl and that of a human, are they the same in all circumstances? Citing Paul Taylor he notes that is it as wrong to kill a flower as to kill a human being? As Cooper (2001) argues some Greens and animals rights advocates see Naess not going far enough for he opined that humans at times because of their 'closeness' can be right in lending help to one another than other non-human beings; and for some scholars he goes too far as the sacrifice he requires of humans he will not 
require of other animals that he claims are equal with humans. Equally for others he is too romantic and mystical and the notion of self-realization cannot form the basis of environmental policy (Cooper 2001). Cooper (2001) says that Naess himself has challenged this noting that the principle of self-realization can inspire action and can be felt and experienced. It is no doubt problematic to place humans on the same par as non-human animals, plants, and organisms. This runs in conflict with African traditional thought, medieval Christian philosophical thought, Islamic thought, and others. It is not necessary that humans have to be placed on the same par with other forms of life before biodiversity can be conserved.

There are certainly challenges against deep ecology. And it would not be possible to list all of them here. The challenges not withstanding there are positive aspects in deep ecology that can help in preservation in the Niger Delta. One of the things that have contributed to biodiversity loss is the human attitude of anthropocentrism and domineering over nature. The perception that nature is there for human utility and that humans can do whatever they desire with nature. Deep ecology affirms that while for essential needs humans can use nature they should not devalue or devastate nature. Humans have a responsibility to conserve and protect. This attitude of ethical with ecological responsibility, need to be accepted by individuals, groups, and oil company in the Niger Delta. Oil companies should be attentive to the tremendous benefits that biodiversity have for humans and also the ecosystem services they render.

This new understanding of self is important. The self is not just the solitary self. Humans are one with and linked with nature and other beings. What impacts nature negatively also impacts humans negatively. In the Niger Delta, with more care and ecological caution, many more species of plants and animals can be preserved. Economic profit is not always more important than the wellbeing of other beings. Preservation of sacred groves and forests at times are vital to even the survival of present and future generations.

Conserving the environment of the Niger Delta requires deep environmental awareness and education. The role of environmental education in the Niger Delta can never be overemphasized. In Naess' own native land, Norway, the notion of self-realization and environmental concern forms aspects of the Norwegian core curriculum and the Latvian Project in Environmental education (Cooper 2001). When people recognize that they are interdependently linked with the earth and other beings, they are more likely going to preserve biodiversity. There is need to renew environmental education in the Niger Delta. Children and many others in the region do go to school without learning about environmental conservation. Rolston (2013) rightly notes that humans have duties to non-human species for 'pragmatic, economic, political and scientific; deeper down it is moral, philosophical, and religious. Species embody fertility on earth that is sacred' ( $p$. 234). Environmental education in the Niger Delta should impact this consciousness in people in the region. Knowledge is important for as the Greek philosopher Socrates opines people err out of ignorance. Though this is not always true, environmental knowledge of the negative impact of human activities in the region and especially of the fundamental reasons to conserve biodiversity can help a great deal in combating the loss. Environmental awareness and education in the Niger Delta need to be deeply enriched with experience of the natural places through field trips, nature tour, excursions, etc. 
People should experience nature not simply in the classroom but in the open field and forests. Experience of natural places was a great emphasis of Naess. Yet, if oil companies destroys most of the natural places and pollute them through their drilling activities it becomes difficult to experience nature in a healthy and peaceful manner. Education against pollution of nature by both individuals and companies should be encouraged. Philosophy has a great role to play in this education in the Niger Delta. Niger Delta philosophers and philosophers in the Niger Delta should campaign and speak for nature. The teachings and writings of philosophers in the Niger Delta should be ecologically transformative and help foster a sustainable environment.

\section{Concluding Reflections}

In this paper after the introduction, the basic concepts that found the work were examined. It also looked at the situation of biodiversity loss in the Niger Delta before examining the philosophy of deep ecology. Some positive aspects of the philosophy of deep ecology were proposed as having potential to help in preserving biodiversity in the Niger Delta. As noted biodiversity is essential and crucial for human and ecosystem survival on earth, and this includes the Niger Delta. Values such as recognizing nonhumans not just as means but as having value in themselves, recognizing that humans are connected to other beings, living a life of sacrifice free from consumerism and luxurious affluence, and working to eliminate what harms other beings are needed in the Niger Delta. Multinational oil companies, other corporate bodies and individuals should imbibe these values and conserve biodiversity in the region for it to be sustainable into the future.

\section{References}

Adeola, F.O. (2009). From colonialism to internal colonialism and crude socioenvironemntal injustice: Anatomy of violent conflicts in the Niger Delta of Nigeria. In F.C. Steady (Ed.), Environmental injustice in the new millennium: Global perspectives on race, ethnicity, and human rights (pp.. 135-163). New York: Palgrave Macmillan.

Agbagwa, I. O. (2014). Oil and gas pipeline construction-induced forest fragmentation and biodiversity loss in the Niger Delta, Nigeria. Accessed on 10 August 2016, from wmw.scirp.org/journal/PaperInformation.aspx?PaperID=49859.

Asthana, D.K., \& Asthana, M. (2010). Environment: Problems and solutions. New Delhi: S Chand \& Company Limited.

Brown, A. (2011). Biodiversity. In G Kutting (Ed.), Global environmental politics: Concepts, theories and case studies (pp.151-163). London: Routledge.

Chambers. (1994). The Chambers dictionary. Edinburgh: Larousse Plc.

Cooker, D.E. (2001). Arne Naess. In J.A. Palmer (Ed.), Fifty key thinkers on the environment (pp. 211-216). London: Routledge.

Curry, P. (2006). Ecological ethics: An introduction. Cambridge: Polity Press.

Demaki, G.O. (2015). Crude oil spills, environmental degradation and corporate social responsibility of oil companies in the Niger Delta of Nigeria. In C. Ewhrudjakpor, A. Atubi, \& L. Etemike (Ed.), Oil theft, environmental degradation and the reciprocal responsibilities of host communities and the government in Nigeria (pp. 78-82). Abraka: Faculty of Social Sciences of Delta State University.

Ekpo, U. (2004). The Niger Delta and oil politics. Lagos: International Energy Communications Limited.

Ekuerhare, B. (2007). Urhobo and the national question: Urhobo's environmental and natural resources. In P.P. Ekeh (Ed.), History of the Urbobo people of Niger Delta (pp.555-562). Buffalo: Urhobo Historical Society. 
Federal Republic of Nigeria. (2006). Niger Delta master plan. Accessed on 10 August 2016, from http://www.nddc.gov.ng/NDRMP\%20Chapter\%201.pdf

Francis, P. (2015). Laudato Si': Encyclical of the holy father Pope Francis on care for our common home. Nairobi: Pauline Publications Africa.

Glazebrook, T., \& Kola-Olunsanya, A. (2011). Justice, conflict, capital and care: Oil in the Niger Delta. Environmental Etbics 33(2): 163-184.

Hook, P. (2008). The little book of environmental principles. London: New Holland Publishers.

Ijaw Youths of the Niger Delta. (1998). Kaiama declaration. Accessed on 10 August 2016, from http://www.unitedijaw.com/kaiama.htm

Ikomi, R.B., \& Arimoro, F. O. (2010). Environmental conservation and management. In S.H.O. Egboh (Ed.), Man, his environment and sustainable development (pp. 234-249). Abraka: Delta State University Press.

Kadafa, A. A. (2012). Environmental impacts of oil exploration and exploitation in the Niger Delta of Nigeria. Accessed on 10 August 2016, from https://globaljournals.org/GJSFR Volume12/2-EnvironmentalImpacts-of-Oil-Exploration.pdf

Keller, D.R. (2009). Deep ecology. In J. B. Callicott \& R Frodeman (Ed.), Encyclopedia of Environmental Ethics and Philosophy (pp. 206-211). Detroit: Gale Cengage Learning.

Micheals, F. (2004). Lotus illustrated dictionary of environmental studies. New Delhi: Lotus Press.

Moro, A.I. (2000). The Niger Delta crisis beyond employment and physical development: The critical issues involved. Port Harcourt: Mind Quest Resources.

Mmon, P.C., \& Arukoyo, S.B. (2009). Mangrove forest depletion, biodiversity loss and traditional resources management practices in the Niger Delta, Nigeria. Accessed on 10 August 2016, from http://pakacademicsearch.com/pdf-files/eng/392/28-34\%20Vol.\%202,\%20Issue $\% 201$ $\% 202010 . p d f$

Naess, Arne. (1973.) The Shallow and the Deep, Long-Range Ecology Movement: A Summary. Inquiry: An Interdisciplinary Journal of Philosophy and the Social Sciences 16: 95-100. (2013). (From) the basis of Deep Ecology. In L Gruen, D Jamieson, \& C Schlottmann (Eds.), Reflecting on nature: Readings in Environmental Ethics and Philosophy (pp. 34- 35). New York: Oxford University Press.

Nwaomah, S. (2011). Eschatology of environmental bliss in Romans 8:18-22 and the imperative of present environmental sustainability from a Nigerian perspective. In F Clingerman \& M H Dixon (Ed.), Placing nature on the borders of religion, philosophy and ethics (pp. 79-94). Surrey: Ashgate Publishing Limited.

Movement for the Survival of the Ogoni People. (1990). Ogoni bill of rights. Accessed on 10 August 2016, from http://www.waado.org/nigerdelta/RightsDeclaration/Ogoni.html

Rajagopalan, R. (2011). Environmental Studies: From crisis to curse. Oxford: Oxford University Press.

Rolston, H. (2013). Biodiversity. In L Gruen, D Jamieson, \& C Schlottmann (Ed.), Reflecting on nature: Readings in Environmental Ethics and Philosophy (pp. 244-255). New York: Oxford University Press.

Smith, P. (1997). Environmental ethics. New York: Paulist Press.

Srivastava, S. (2010). Environmental Science and ethics. New Delhi: S K Kataria \& Sons.

Stranks, J. (2008). The a-z of the environment: A complete guide to all the issues-scientific, legal, economic and social-and their impact on business and government. London: Thorogood Publishing Limited.

Taylor, B., \& Zimmerman, M. (2008). In B Taylor (Ed.), Encyclopedia of religion and nature: Volume 1(A-J), (pp. 456-459). London: Continuum.

Ukaga, O., Ukoha O U, \& Ibaba, I S. (Ed.). (2012). Natural resources, conflict, and sustainable Development: Lessons from the Niger Delta. New York: Routledge.

Ugochukwu, C. N. C., \& Ertel, J. (2012) Negative impacts of oil exploration on biodiversity management in the Niger Delta area of Nigeria. Accessed on 10 August 2016, from http://www.tandfonline.com/doi/abs/10.3152/146155108X316397A

United Nations. (1972). United Nations Conference on the environment. Accessed on 10 August 2016, from http:/ $/$ www.unep.org/documents.multilingual $/$ default.asp?documentid=97\&articleid=1503

United Nations. (1992). Convention on biological diversity. Accessed on 10 August 2016, From https://www.cbd.int/convention/ 
United Nations Development Report. (2012). Niger Delta biodiversity project. Accessed on 10 August 2016, from http://www.undp.org/content/dam/undp/documents/projects/NGA/Niger\%20Delta\%20Bi odiversity Prodoc.pdf

Zabby, N. (2004). Impacts of extractive industries on the biodiversity. Accessed on 10 August 2016, from www.cehrd.org/files/IMPACTS_OF_EXTRACTIVE3.doc 